ARTICLE

\title{
Sketches of Black People by White Catalan-Cuban Intellectuals: Transculturation in Fernando Ortiz's and Jaume Valls's Afrocubanismo in 1920s Havana
}

\author{
Yairen Jerez Columbie \\ University College Cork, IE \\ yairen.jerez@gmail.com
}

\begin{abstract}
The study of the raise of Afrocubanismo enables understanding of how, during the 1920s, Cuban nationalism adapted in order to exploit the recombinant qualities common to the territories of the Caribbean. Drawing on Fernando Ortiz's, Stuart Hall's and Paul Gilroy's theories on the formation and construction of identities, this article brings a focus on the positions of enunciation within the practices of representation of blackness by cultural theorist Fernando Ortiz and visual artist Jaume Valls, in order to illustrate their role and the role of other members of the Catalan-Cuban intellectual community in the movement of Afrocubanismo and the reshaping of the idea of Cuban national identity during the 1920s. The analysis includes a comparison of graphic artists Lluís Bagaria's and Jaume Vall's representations of blackness in the Catalan-Cuban journal La Nova Catalunya (Havana, 1908-1959) in order to illustrate the processes of transculturation expressed through the representation of black subjects in the journal as part of the wider processes of recreation of identities within the Catalan-Cuban intellectual community during the first three decades of the twentieth century. The article addresses the limitations of nationalistic points of view to grasp de complexities of diasporic realities and highlights the usefulness of the concept of transculturation to understand processes of formation of identities in twentieth-century Cuba.
\end{abstract}

Keywords: identities; race; transculturation; nationalism; hybridity

I move slowly in the world, accustomed now to seek no longer for upheaval. I progress by crawling. And already I am being dissected under white eyes, the only real eyes. I am fixed. Having adjusted their microtomes, they objectively cut away slices of my reality. I am laid bare. I feel, I see in those white faces that it is not a new man who has come in, but a new kind of man, a new genus. Why, it's a Negro! (Fanon 420)

The history of the Catalans of America, as other narratives of migration, exemplifies how culture flows out of patterns congruent with the borders of nation states. This paper brings a focus on the positions of enunciation within the practices of representation of cultural theorist Fernando Ortiz and visual artist Jaume Valls, in order to illustrate their role and the role of other members of the Catalan-Cuban intellectual community in the movement of Afrocubanismo and the reshaping of the idea of Cuban national identity during the 1920s. The first section of this article addresses the limitations of nationalistic points of view to grasp the complexities of diasporic realities and the inadequacy of terms such as creolization, métissage, mestizaje, syncretism and hybridity to appeal ethnicity and the complex processes of cultural mutation. The second part focuses on the key role of Fernando Ortiz within both Cuban society and the Catalan-Cuban community during the nation-making processes of the 1920s. Finally, I compare graphic artists Lluís Bagaria's and Jaume Valls' visual representations of blackness in the Catalan-Cuban journal La Nova Catalunya (Havana, 1908-1959) in order to illustrate the processes of transculturation expressed through the representation 
of black subjects in the journal as part of the wider processes of recreation of identities within the CatalanCuban intellectual community during the first three decades of the twentieth century. ${ }^{1}$

La Nova Catalunya was a Catalan-Cuban journal written in Catalan language between 1908 and 1959 in Havana. The mathematician and professor of La Universidad de La Habana, Claudi Mimó i Caba and the writer and journalist Josep Conangla i Fontanilles became its foremost figures. Both intellectuals, and particularly Conangla, were the leaders of the nucleus of the Centre Català of Havana and the secret organization Club Separatista Número 1, created in 1922 to coordinate an intense activity in favor of Catalonia's independence from Spain and organize the constituent assembly of Catalan separatism and the consequent signing of the First Catalan Constitution in Havana, in 1928. The two main figures of the Centre Català of Havana and La Nova Catalunya, Claudi Mimó and Josep Conangla exemplify the appropriateness of the epithet "CatalanCubans" given to those Catalan migrants that participated intensely in both the cultural and political life of Cuban society. ${ }^{2}$ Claudi Mimó immigrated to Cuba in 1883, was affiliated to the Cuban Liberal Party, and had responsibilities in the City Council of Havana. Mimó was president of the Real Sociedad Económica de Amigos del País and of the sciences section of the Ateneo of Havana and, for many years, worked as a professor in the University of Havana. Josep Conangla i Fontanilles arrived for the first time in Cuba in 1895 to fulfil the obligatory military service until 1898. He came back to the island in 1901 as an economic immigrant. Josep Conangla worked on the Cuban newspapers El Nuevo País, Cuba, El Nuevo Día, El Mercurio, La Noche and El Sol, founded Revista Parlamentària de Cuba and he was copy editor of the Minutes of the Cuban Parliament, founder of the first Cuban journalistic association, Asociación de Reporteros de La Habana, and was a member of the Sociedad Económica de Amigos del País, the Sociedad Geográfica de Cuba, the Sociedad Cubana de Autores and the Sociedad Bibliográfica de Cuba. He has been considered a precursor of avant-garde poetry in Latin America and Catalonia and his political and philosophical essays are key documents for the study of nation-making processes in the Atlantic, in which Afrocubanismo is embedded. ${ }^{3}$ The history of these and other diasporic subjects has helped configure the diverse uniqueness of the Caribbean and its multiple, porous and constantly evolving cultural identities:

Cultural identities come from somewhere, have histories. But, like everything which is historical, they undergo constant transformation. Far from being eternally fixed in some essentialized past, they are subject to the continuous 'play' of history, culture and power. Far from being grounded in a mere 'recovery' of the past, which is waiting to be found, and which, when found, will secure our sense of ourselves into eternity, identities are the names we give to the different ways we are positioned by, and position ourselves within, the narratives of the past. (Hall 236).

\section{Transculturation in the black atlantic}

In The Black Atlantic, Paul Gilroy alerts on the limitations of nationalistic points of view within cultural studies and invites us to reshape the sense of contemporary nations itself by reinterpreting the cultural core of its supposedly authentic life. It is by going beyond national and nationalistic perspectives that we can perceive and understand the realities that show the fallacy of the non-ethic and non-scientific ideas about

\footnotetext{
${ }^{1}$ From 1908 onwards, Lluís Bagaria (Barcelona, 1882-Havana, 1940) toured the United States, Mexico and Cuba with Enric Borràs's theatre company. Even though he died in Havana in 1940, aside from these early collaborations during 1908 and 1909, there are no signs of further linkage to La Nova Catalunya. Jaume Valls (Tarragona, 1883-Havana, 1955) was a graphic artist and painter who developed his career in Cuba, where he arrived when he was 18 years old. Some of his works are part of the permanent exhibition of the Museo Nacional de Bellas Artes in Havana.

${ }^{2}$ Claudi Mimó i Caba (Vilanova i la Geltrú, 1843-Havana, 1929), founder of the Centre Català and La Nova Catalunya. In 1921 he travels to Catalonia and, as a representative of the Catalan in Cuba, establishes contacts with the government of Catalonia (the Mancomunitat), the City Council of Barcelona, the Associació Protectora de l'Ensenyança Catalana, Unió Catalanista and the Lliga Regionalista. There is no in-depth study about his life and work, despite his important role in the Catalanist movement and in the Cuban School of Mathematics. Josep Conangla i Fontanilles (Montblanc, 1875-Havana, 1965) arrived in Cuba for the first time in 1895, as a soldier of the Spanish army, and remained in the country until 1898. Conangla i Fontanilles (1998) recollects his experiences as a member of the Spanish colonial expeditionary force in the Cuban war of independence (1895-1898) in the book Memorias de mi juventud en Cuba: un soldado del ejército español en la Guerra separatista (1895-1898), which was translated into English in 2017. In 1904, he came back to the island, where he worked as a journalist and led the Catalanist intellectual group of the Centre Català of Havana during the first half of the twentieth century.

${ }^{3}$ Joaquín Roy (1989) has studied Conangla's poetry included in the volumes Elegía de la guerra (1904), El meu pare que al cel sia (1920) and Eternal (1921). In 1916, Josep Conangla i Fontanilles published La ciudadanía adoptiva, an essay that defends both the Catalan and the Cuban identities of members of the Centre Català who had adopted Cuban citizenship. In the same vein, his essay Martí y Cataluña (1954), published as part of the commemorative events and publications on the occasion of the centenary of the Cuban national hero, is a document that testifies to Conangla's deep knowledge of José Martís works.
} 
the purity of cultures and the confusion of the concepts "ethnicity" and "culture", a problem addressed also by Marc Augé:

Living cultures are receptive to outside influences; in one sense, all cultures have been contact cultures; but it is what they make of these influences that is interesting. We sometimes are inclined to regard culture and ethnicity as reflections of one another, turning the intangibility of the former into the condition of the latter's existence. Within this perspective any penetration from the outside is regarded as de-culturation as de-socialisation, a loss of identity. If on the contrary we take into account that all culture is living, then contact and the testing out of the other, are rather an opportunity for confirmation. (Augé 17)

This study of the cultural production published in a journal linked to a Catalan-Cuban activism, with origins in Europe but geographically located in the Caribbean, also recognizes the limitations of the culturalistic understanding of ethnicity, not only within the Catalanist movement, but within epistemological perspectives. In opposition to both the ethnocentrist and the culturalistic ethnically absolute approaches, Gilroy develops the suggestion that "cultural historians could take the Atlantic as one single, complex unit of analysis in their discussions of the modern world and use it to produce an explicitly transnational and intercultural perspective" (Gilroy 14-15). Gilroy's conception of the black Atlantic presents us this countercultural wide perspective within cultural studies for exploring the realities of a region clearly mediated by diaspora, whose history is related not only to our islands, but also to Africa, Asia and Europe.

It is precisely the predominant ethnocentric nationalistic focus within some areas of cultural studies, the source of the inadequacy of terms such as creolisation, métissage, mestizaje, syncretism and hybridity to name what Gilroy calls "the processes of cultural mutation and restless (dis) continuity that exceed racial discourse and avoid capture by its agents" (2). Even though these equivalent notions appeared in opposition to the concepts of culture that present ethnic differences as an absolute, they legitimate the outmoded idea about the authenticity of some cultures, whose combination gives as a result some other type of unit susceptible of being qualified as hybrid. Over the ideas of creolisation, métissage, mestizaje syncretism and hybridity, which seem more focused on the result than on the process, soars the idea of the existence of a Fatherland or a Motherland, which is contrary to the "Anti-Oedipal" ${ }^{4}$ flows of cultures and identities of the black Atlantic and its peoples' desire ${ }^{5}$ to escape the restrictive bonds of ethnicity and national identification.

In his own search of categories that could comprehend the richness of the realities of the Caribbean, Fernando Ortiz (1977) proposed the term "transculturation" as a substitute for the term "acculturation", whose use was spreading by the year of first publication of his book Contrapunteo cubano del tabaco y del azúcar (1940) (translated as Cuban Counterpoint in 1947). According to the anthropologist, "acculturation" was used to describe the process of transition from one culture to another, and its manifold social repercussions, but "transculturation" was more a fitting term to express the highly varied phenomena that come about in Cuba as a result of its extremely complex transmutations of culture. Ortiz highlights how the actors of these processes arrived, either in sporadic waves or a continuous flow, from different lands of Africa and Spain, but also from France, Portugal, China, the United States and other territories. As Fernando Ortiz reminds us, they were all exerting an influence and being influenced in turn, and all of them were faced with the problem of disadjustment and readjustment, of deculturation and of inculturation, in a word, of transculturation:

Entendemos que el vocablo transculturación expresa mejor las diferentes fases del proceso transitivo de una cultura a otra, porque éste no consiste solamente en adquirir una distinta cultura, que es lo que en rigor indica la voz angloamericana acculturation, sino que el proceso implica también necesariamente la pérdida o desarraigo de una cultura precedente, lo que pudiera decirse una parcial desculturación, y, además, significa la consiguiente creación de nuevos fenómenos culturales que pudieran denominarse de neoculturación. Al fin, como bien sostiene la escuela de Malinowski, ${ }^{6}$

\footnotetext{
${ }^{4}$ Michel Foucault's introduction to Deleuze and Guattari's Anti-Oedipus (1985) offers a clear overview of the adjective: "Against the Oedipal and oedipalized territorialities (Family, Church, School, Nation, Party) and specially the territoriality of the individual, Anti-Oedipus seeks to discover the 'deterritorialized' flows of desire, the flows that have not been reduced to the Oedipal codes and the neuroticized territorialities, the desiring-machines that scape such codes as lines of escape leading elsewhere" (Foucault xvii).

${ }^{5}$ Paul Gilroy describes this "desire" in relation to the experiences of intellectuals of the black Atlantic: "Whether this experience of exile is enforced or chosen, temporary or permanent, these intellectuals and activists, writers, speakers, poets, and artists repeatedly articulate a desire to escape the restrictive bonds of ethnicity, national identification, and sometimes even 'race' itself" (Gilroy 19).

${ }^{6}$ In his introduction to the first edition of Contrapunteo cubano del tabaco y el azúcar (1940), anthropologist Bronislaw Malinowski
} 
en todo abrazo de culturas sucede lo que en la cópula genética de los individuos: la criatura siempre tiene algo de ambos progenitores, pero también siempre es distinta de cada uno de los dos. En conjunto, el proceso es una transculturación, y este vocablo comprende todas las fases de su parábola. $(\text { Ortiz } 96)^{7}$

Without exhausting the complexity of the processes resulting from diasporic experiences and cultures contact, "transculturation" seems a more accurate term to appeal the reshaping of identities, as it includes both the uprooting and the process of putting down roots, the lost and the gain, as contradictory constitutive parts of the same reality. The term includes the (dis)continuity addressed by Gilroy in his description of the richness of the processes of cultural mutation and is most precise on describing the phenomena of becoming someone new.

The transculturation experienced by the Catalan-Cuban nationalist intellectual community is located within a wider process of cultural mutation within Cuban society that led to the reformulation of Cuban nationalism by the 1920s. As Robin Moore reminds us, "nationalist discourse is inevitably contested and thus must constantly change, accommodating itself to new criticisms and new social realities" in order to maintain its hegemony (115). Moore discusses the social conditions that gave rise to the sudden vogue for Afrocubanismo in the 1920s, a phenomenon that was expression of the climax of the process of transculturation that had been ongoing in Cuban society since 1492-when the first massive population movements began-and reached a climax in the twentieth century, after independence.

\section{Afrocubanismo as transcultural expression}

The study of the rise of Afrocubanismo enables understanding of how Cuba's historically established white nationalism adapted in order to rationalize and exploit the transcultural qualities common to the territories of the Caribbean in a time of economic and political crisis. This upsurge of interest in Afrocuban subjects without precedent in Cuban history, was the hegemonic white liberal class' answer to the impossibility of continuing to create ideological unity without recognising the diversity of Cuban society and the significant representation of the Afro-descendants. ${ }^{8}$ This situation was exacerbated by the economic crisis of the 1920s and the 1930s, the increase in corruption and repression during the government of Gerardo Machado (1925-1933) and subsequent political instability.

The main actors of Afrocubanismo were white middle-class individuals who mostly represented black Cuban culture from a perspective shaped by estrangement. ${ }^{9}$ Indeed, among their number were none other than Catalan-Cuban Ferran (or Fernando) Ortiz, Emili (or Emilio) Roig de Leuchsenring and Jaume (or Jaime) Valls, agents of the new hegemonic middle-class of liberal professionals and intellectuals, in which Catalan immigrants and descendants had featured prominently, as indeed they had done during the nineteenth century in the hegemonic industrial class.

In an article published in 1929 in the section "Cubans il-lustres, amics de Catalunya" (Illustrious Cubans, friends of Catalonia), the editorial voice of the journal describes Fernando Ortiz as one of the most illustrious Cubans because of his books, intellectual and social activities and public responsibilities. La Nova Catalunya (1929 February 13) presents him as lawyer, journalist, publicist, diplomat, anthropologist, professor, sociologist, historian, tireless scholar of all cultural topics and one of the most prominent Cuban intellectuals.

highlights the importance of Ortiz's concept of transculturation within the social sciences. Fernando Coronil describes the evolution of Malinowski's early apparently impartial anthropology towards a historically positioned practice: "Malinowski's acknowledgment suggests how Ortiz's ideas helped him view cultural transformations from a nonimperial perspective and support the claims of subject peoples" (Coronil xlvi).

7 We understand that the word transculturation better expresses the different phases of the transitional process from one culture to another, because this does not only consist in acquiring a different culture, which is what the Anglo-American voice acculturation strictly indicates; the process also necessarily implies the loss or uprooting of a previous culture, which could be called a partial deculturation, and also means the consequent creation of new cultural phenomena, which could be called neoculturation. After all, as the Malinowski school well maintains, in every embrace of cultures, as in the genetic copulation of individuals, the child always has something of both parents, but it is also always different from each of the two. Altogether, the process is a transculturation, and this word encompasses all the phases of its parabola.

${ }^{8}$ Aline Helg has studied the armed revolt of the anti-racist party Partido Independiente de Color in 1912 and the subsequent massacre of its members by the professional troops of the Government, which are evidence of the magnitude of the conflicts within Cuban society.

${ }^{9}$ The term Minoristas refers to the artistic minority or elite promoting Afrocubanismo and shaping Cuban artistic avant-garde, as explained by Cairo, Bojórquez and Roig de Leuchsenring. In addition, Robin Moore highlights that they came from relatively wealthy backgrounds, were generally white, well educated, and often prominent social and political leaders: "Minorista artists kept abreast of progressive intellectual currents in Europe and the United States and created unique works that demonstrate both the influence of Afrocubanismo nationalism and of modern aesthetics in the form of cubism, serialism, atonality, and other styles" (Moore 191). 
At that time Ortiz was president of the Sociedad Económica de Amigos del País, the Academia Nacional de Historia and the Sociedad Hispano-Cubana de Cultura, director of the journals Revista Bimestre Cubana and Archivos de Folklore Cubano. Although the text stresses Ortiz's Cubanness, it also clarifies his attachment to Catalonia. Shortly after his birth in Cuba, in 1881, he had been taken to the Balearic Islands, where he began his studies and published his first essay, the first steps in an intellectual experience whose imprint-according to the journal-was perceptible in Ortiz's accent.

In a speech delivered on 11 September 1918 in the celebration of the Catalan Diada at the Centre Català, Ortiz mentions Catalan intellectuals who played important roles in the configuration of the Cuban nation: Marià Cubí i Soler, founder of the journal Revista Bimestre Cubana, publication of the Sociedad Económica de Amigos del País, created in 1892 to promote the economic and cultural development of Cuba; the revolutionary Ramón Pintó, president of the Liceo de La Habana, sentenced to death in 1855 for plotting in favour of the independence of Cuba; Federico Capdevila, defense attorney of the medical students sentenced to death by firing squad in 1871 after being accused, without evidence, of having scratched the glass on the tomb of a journalist loyal to Spain; and Catalan politician Francisco Pi i Margall, who positioned himself in favour of the independence of Cuba and against the intervention of the United States during the war of $1895-1898 .{ }^{10}$ The applause provoked by these names among the attendees, and documented in the printed version of the speech, reveals the importance of these historical figures within the imaginary of the Catalan community of Cuba. The position of Cubí i Soler, Pintó and Capdevila in the political and cultural life of Cuba is backed by the general economic status of the Catalan community during the nineteenth century, in which, as pointed out by the historian Eduardo Torres Cuevas, landowners and traders, mainly Catalans, vied for dominance (276-81). In a study about the journal La Llumanera de Nueva York, Lluís Costa describes the nineteenth century Catalan commercial and industrial bourgeoisie as a social class associated with the Spanish colonial power and moved by economic interests. It is in the light of these historical facts that the qualitative relevance of the exceptional figures referenced by Ortiz should be understood.

Even though by the 1910s the Catalan community was heterogeneous and very different from that of the previous century, both the higher level of formal education of Catalan immigrants in comparison to other migrants from the Iberian Peninsula and the economic power achieved by members and institutions of the Catalan community during the nineteenth century, determined a more prominent presence of Catalan intellectuals in positions of both symbolic and effective power within Cuban society. Ortiz's positionings should be analyzed in the light of this reality that shaped his position of enunciation as a member of both a new Cuban Republic and of institutions of colonial heritage, such as the Sociedad Económica de Amigos del País.

Robin Moore has described the evolution of Fernando Ortiz's attitudes towards Afrocuban cultural practices and states that before the 1920s Ortiz's writings demonstrated a disdain for African-influenced expression. The author brings in the less known facet of Fernando Ortiz as a witness for the prosecution of Afrocuban religious leaders by the Cuban government, and states that his "interest in Africanisms stemmed initially from a desire to better understand and remedy the social ills of the nation perpetuated by blacks" (Moore 34), which can also be perceived through his condemnation of santería in his work Hampa afrocubana, los negros brujos [Afro-Cuban Underworld, Black Sorcerers] (1906)..$^{11}$ The latest intellectual phase of Fernando Ortiz, characterized by the defense of Afrocuban studies and the fight against racism, is best known. In 1936, the Catalan-Cuban anthropologist founded the Sociedad de Estudios Afrocubanos, the first institution devoted to the study of Afrocuban culture. Some of its members were the musicians Alejandro García Caturla, Amadeo Roldán and Gonzalo Roig, the poets Nicolás Guillén and Regino Pedroso, the actress Eusebia Cosme, and the political activists and members of the Centre Català of Havana, Juan Marinello and Emili Roig de Leuchsenring. Even though, some of the members of the organization were black intellectuals, the studies published in the quarterly journal Estudios Afrocubanos (1937-1940; 1945-1946) were generally conducted from an external perspective and did not openly reflect the marginalization of black people. By that time, Fernando Ortiz was not only influential within Cuban society but also inside the Catalan intellectual community, as evidenced by the many references to his figure in La Nova Catalunya, like the photography published in the front page of the edition of October 1918. Nevertheless, the fact that he was selected to deliver the lecture of the patriotic Catalan festivity of 11 September is more eloquent than any of the epithets the journalists of La Nova Catalunya used to praise him.

Echoing works by Aline Helg and Maria Poumier about the presence of evolutionist and racist ideologies in Fernando Ortiz's work and its context of production, Fernando Coronil invites to transcend polarized

\footnotetext{
${ }^{10}$ Coincidently, some of these figures would be recovered by Josep Conangla i Fontanilles (1925), in a public lecture transcribed in La Nova Catalunya, in which he offers biographical notes on Catalan intellectuals and politicians who worked in favour of Cuban institutions.

${ }^{11}$ Moore attributes this information to Ortiz's personal communication with Aline Helg (34).
} 
readings and to take into account the complex dynamic between Ortiz's ideas and dominant ideologies: "The challenge is to appreciate at once Ortiz's striking transformation and its limits, given the origins of his work in racist ideologies and his position as an elite intellectual under changing political regimes" (Coronil I). A comparative reading of the works published by Fernando Ortiz at the early stage of his career and those conceived from the 1920s, shows his evolution towards a more inclusive cultural approach to both ethnicity and national identity. As Rafael Rojas has pointed out, the author of Hampa afrocubana (1906) progressed from a positivist paradigm to an idea of culture in which Cuban national identity appears as an historical construction by successive ethnic immigrations. This evolution led Ortiz to bring the diverse and irreducible cultural elements of the Cuban context into national discourse through his concept of transculturation and the metaphor of ajiaco in the 1940s. ${ }^{12}$ Nevertheless, an example of this use of the interstices of (in)definition and the volatility of Cuban identities to support national discourse can be found in the reformulation of Cuban nationalism from the 1920s onwards, through the artistic, cultural, ideological and political movement of Afrocubanismo, of which Ortiz was a founding figure.

The editorial voice of La Nova Catalunya (February 1929) relates Ortiz's trip to Spain on the occasion of being awarded the medal of honorary member of the Sociedad Económica de Madrid in 1928. The journal reproduces the lecture delivered by the Catalan-Cuban intellectual in Madrid on the diversity of the Hispanic world, a text that criticizes the "Hispanist propaganda" behind political concepts that ignore the different traditions, religions, international interests and political positions of the people who speak Castilian. This neglect is an error, says Ortiz, as serious as frequent:

Dañan también los "utopismos" de los idealistas, que por fuerza de su ensoñación o por afán de estridencia desearían arrastrar las corrientes hispánicas por torrenteras y despeñaderos a remansos y mares que sólo son espejismos.

Perturban lo mismo, las más alardeadas, que ciertas aspiraciones hegemónicas de un pueblo o grupo sobre otro, que aun cuando limitadas a lo espiritual, hieren la susceptibilidad patriótica, santamente exacerbada, de las naciones de América, para las cuales la hiperestesia de su patriotismo es, a veces, necesaria, obligadas como están a una continua vela de armas contra toda fuerza que sea o aparezca como debilitadora de su integridad espiritual. (Ortiz in La Nova Catalunya, February $1929,14)^{13}$

In this speech, Ortiz criticizes the ideas that neglect the legitimacy of distinct beliefs and personal philosophical positionings that could be harmonized in the context of Hispanic culture. He also highlights the dangers behind racist ideas and the concept "race" and invites his audience to adopt the more appropriate concept "culture" to define the unity of the diverse Hispanic world:

La raza es concepto estático; la cultura, lo es dinámico. La raza es un hecho; la cultura es, además, una fuerza. La raza es fría, la cultura es cálida. Por la raza sólo pueden animarse los sentimientos; por la cultura, los sentimientos y las ideas. La raza hispánica es una ficción, generosa si se quiere; pero la cultura hispánica es una realidad positiva, que no puede ser negada ni suprimida en la fluencia de la vida universal. La cultura une a todos; la raza sólo a los elegidos o a los malditos. De una cultura puede salirse para entrar en una cultura mejor, por autosuperación de la cultura nativa o por expatriación espiritual y alejamiento de ella. De su raza propia, nadie puede arrepentirse; ni aun puede con un encomio propagarla, porque al extraño nunca le será dado adquirirla, ni aun en la sangre de sus hijos. (Ortiz in La Nova Catalunya, February 1929, p. 14-15) ${ }^{14}$

\footnotetext{
${ }^{12}$ Ajiaco is a Cuban traditional stew that combines meats and vegetables of diverse origin. Fernando Ortiz used this term as metaphor of Cuban society in 1949.

${ }^{13}$ The utopic views of those idealists whose dreaminess or rush for stridency makes them want to drag the Hispanic streams down gullies and cliffs to mirages of backwaters and seas, are harmful. Equally upsetting are the vaunted aspirations of a country over another. Even when limited to the spiritual realm, they offend the sacredly heightened patriotic susceptibility of the American nations, for whom the hyperesthesia of its patriotism is at times necessary, because they are compelled to be vigilant against any power that either is or could emerge as a threaten to its spiritual integrity.

${ }^{14}$ Race is a static concept; culture is dynamic. Race is a fact; culture is also a pull. Race is cold, culture is warm. Race can only boost feelings; culture can animate both feelings and ideas. Whereas the Hispanic race is a fiction, generous perhaps; the Hispanic culture is a positive reality that cannot be denied or suppressed from the current of universal life. Culture unites everyone; race brings together only the chosen ones or the outcasts. A person can leave a culture to enter a better one, either because of selfimprovement, expatriation or distance from the native culture. Nobody can regret their own race, nor disseminate it through praise, because for the outsiders, it is not a given to get it, not even in the blood of their sons.
} 
Without abandoning the concept "race", Ortiz stresses its inadequacy to grasp the complexities of social and cultural history and reminds his Spanish audience that there are countries overseas where the idea of race has demographic, political, historical, and even economic meanings that are unimagined in Spain. The author's notion of culture is coherent with the culturalistic voluntarist nationalism advocated by Cuban Catalanism in the Catalan Constitution of Havana (1928) and recognizes the right of people of all colors and genetic backgrounds to be part of a chosen/elected culture, an idea that was, by that time, reshaping the historically white Cuban nationalism. These reformulations would be expressed, years later, in the article 20 of the Cuban Constitution of 1940:

Todos los cubanos son iguales ante la Ley. La República no reconoce fueros ni privilegios. Se declara ilegal y punible toda discriminación por motivo de sexo, raza, color o clase, y cualquiera otra lesiva a la dignidad humana. La Ley establecerá las sanciones en que incurran los infractores de este precepto. (Cuba Constitución Política de 1940, art. 20) ${ }^{15}$

\section{A comparison of sketches of black people in La Nova Catalunya}

A comparison of the first representations of black people in La Nova Catalunya in the late 1900s with images published in the late 1920s shows the evolution of more open attitudes to diversity within both Cuban society and the Catalan-Cuban intellectual community. The first images of black people that appeared in the journal were drawn by caricaturist Lluís Bagaria i Bou (1909) as part of the vignette 'Auca cierta y verdadera d'en Joan Valldepera'. ${ }^{16}$ The cartoon tells the story of Joan Valldepera, a young Catalan man who leaves Catalonia in pursuit of a better future and establishes himself in Havana, where he gets married to a Cuban woman and gets rich from the success of his beans business. In addition to be the typical story of migrant success, the vignette presents a superficial and patronizing image of both black people and women. ${ }^{17}$ The black woman the protagonist marries is "humorously" introduced with the Catalan expression "una rossa com fil d'or" (blonde as a string of gold), and her black relatives are also deprived of both their belonging to Cuban culture and their capacity to be self-sufficient through the phrase that indicates that Valldepera "carregà amb els somalís" (he took care of the Somalis). Even though Joan Valldepera's black wife and children appear reading in the last drawing of the vignette, which adds a slightly more enlightened perspective to the portrait, Bagaria reproduces the stereotypical depiction of black people common in early representations of blackness in Western culture:

Stereotyping of blacks in popular representation was so common that cartoonists, illustrators and caricaturists could summon up a whole gallery of 'black types' with a few, simple, essentialized strokes of the pen. Black people were reduced to the signifiers of their physical difference - thick lips, fuzzy hair, broad face and nose, and so on. (Hall 249)

Although Bagaria's vignette could be read as a step towards the normalization of representations of interracial marriage, its failure to represent black people reveals the strength of the simplifying approach of the dominant white gaze in 1900s Cuba. The presence of this form of symbolic violence against black subjects in the pages of La Nova Catalunya reveals the wider problem of the prevalence of racial prejudices in a sociohistorical context shaped by conquest, slavery, colonialism and postcolonial reconstruction. It is important to recall that this vignette was published in 1908, shortly before the racist massacre of Afrocubans by the Cuban army aimed at annihilating the Partido Independientes de Color, in 1912, and the outburst of racism that, according to Aline Helg's studies, were reflected in social thinking. The institutionalized racial discrimination and the subsequent claims of blacks and Afro-descendants would force the historically white Cuban

\footnotetext{
15 All Cubans are equal before the Law. The Republic does not recognise exemptions or privileges. Every discrimination against anybody on the basis of sex, race, colour or class, or any other reason detrimental to human dignity is declared illegal. The Law will stablish penalties for the infringers.

16 From 1908 onwards Lluís Bagaria toured the United States, Mexico and Cuba with Enric Borràs's theatre company. He died in Havana in 1940, but aside from these early collaborations during 1908 and 1909, there are no signs of further collaborations to $\mathrm{La}$ Nova Catalunya.

${ }^{17}$ La Nova Catalunya published caricatures of white intellectuals throughout its existence, in line with its focus on waving narratives around the success of Catalan immigrants, as studied by Jerez Columbié $(2014,2018)$. However, Bagaria's vignette is the only strip cartoon, or series of cartoons telling a story, that has been identified in the collection of the journal at the Pompeu Fabra archive of the Sociedad de Beneficencia de Naturales de Cataluña of Havana, which limits the possibilities for comparative studies.
} 
nationalism to adapt and include elements of the black cultures into both artistic and political discourses from the 1920s onwards.

In contrast with Bagaria's childlike "black types" of the 1900s, the Catalan-Cuban artist Jaume Valls offers more realistic and humanized black figures in the series of drawings Tipos de son, published in La Nova Catalunya in 1927. The first of two pieces, titled 'El músic de les maraques', appeared in June, and portrays a black musician seated on a stool, apparently contorted by the sounds produced by his instruments. The second drawing, which was published in August and entitled 'El músic del bongó', shows a black musician seated on a chair playing a bongo held between his legs.

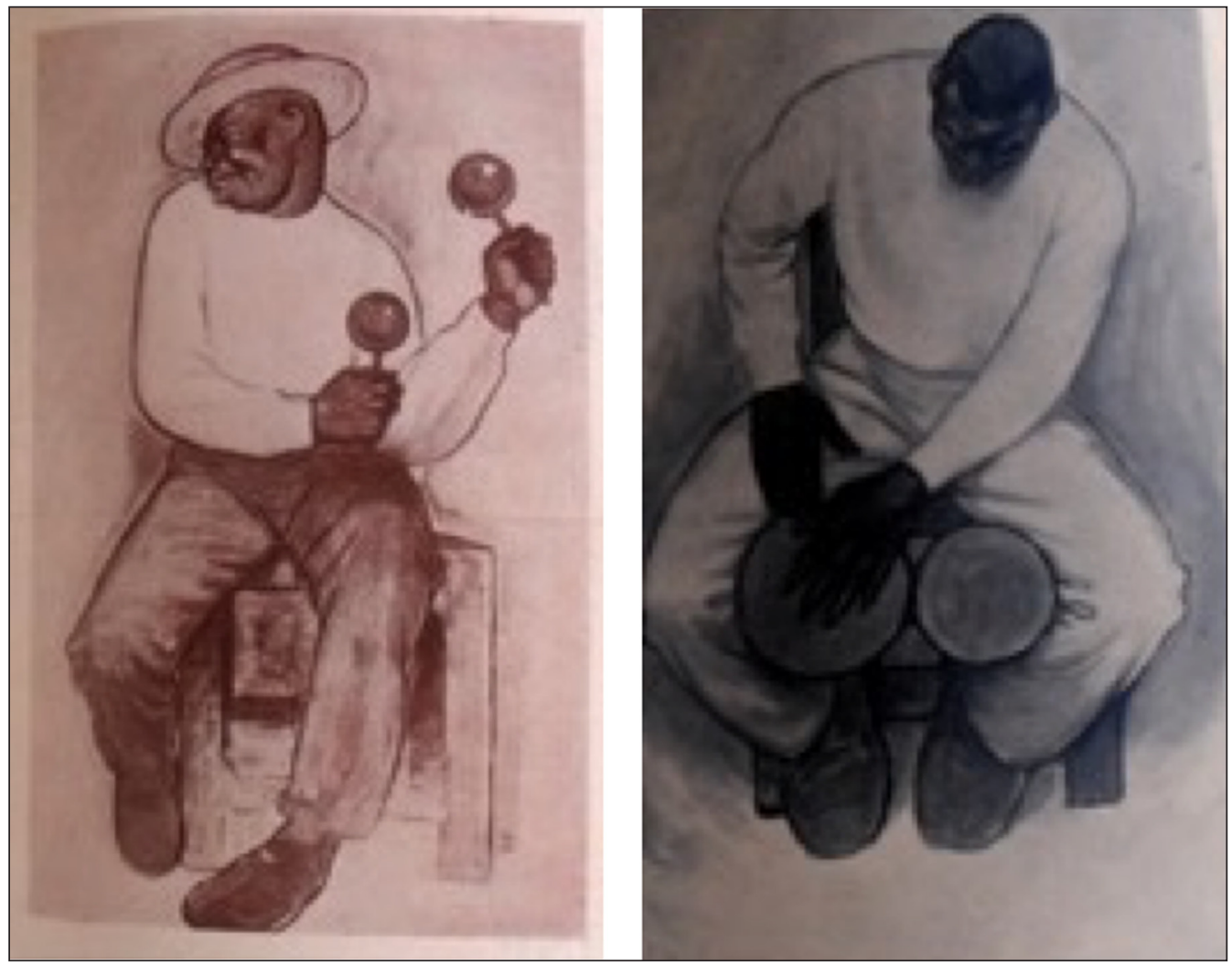

Left: 'El músic de les maraques' by J. Valls. (La Nova Catalunya, 1927, June, cover page).

Right: 'El músic del bongó' by J. Valls. (La Nova Catalunya, 1927, August, cover page).

In both pieces the men seem to have surrendered to the rhythm of their instruments, the maracas and the bongo, which were just beginning to be recognized as core instruments of Cuban music alongside other black musical instruments like the Cuban claves or the marímbula. Jaume Valls's work begins to grasp the complexity of the black components of Cuban culture; his black people are not reduced to the signifiers of their physical attributes and, even though his images could be interpreted as reductive in so far as black people are shown only in relation to their performative capacities, there is an evident qualitative leap in the resources used for their representation. By comparing Bagaria's and Valls's works, it is possible to perceive an evolution from a sense of estrangement to a familiarity before lo cubano.

Nevertheless, Valls' drawings 'Tipos de son' remain reduced to a set of attributes historically associated with black people in the type of colonial discourse contested by Franz Fanon (1969) in Black Skins, White Masks, through his idea of fixation, later revisited by Homi Bhabha: "An important feature of colonial discourse is its dependence on the concept of 'fixity' in the ideological construction of otherness" (Bhabha 370). Valls's continuing colonial approach to black otherness is not an exception but an exemplification of the common pattern of representation within Afrocubanismo, and of the external and prejudiced approach of middle-class white intellectuals to the reality and the identities of working-class black men and women.

Jaume Valls (Tarragona, 1883-Havana, 1955) was 18 years old when he arrived in Cuba. In 1908, he created the company Propagandas Artísticas Valls and, during the following years, built his artistic career in close relationship with the development of Cuban graphic arts and advertising. At present, some of his pieces are included in the permanent exhibition of the Museo Nacional de Bellas Artes in Havana. Emilio 
Roig de Leuchsenring described him as the first Cuban visual artist who dedicated himself completely to Cuban artistic creation through the representation of Afrocuban types and traditions:

es Jaime Valls el primero de nuestros artistas que ha tomado la resolución, que algunos calificarán como heroica, de consagrarse por completo a hacer obra cubana, escogiendo como motivos y temas, tipos y costumbres afrocubanos. (Roig de Leushsenring 68). ${ }^{18}$

At a time when "many still did not wish to accept Afrocuban inspired expressive culture as Cuban and proposed instead images of the Cuban guajiro (The Hispanic peasant) and the Indian as alternate national symbols" (Moore 116), Jaume Valls was a pioneer in incorporating a mostly realistic and coherent representation of black people to the Cuban imaginary. Painters Eduardo Abela, Carlos Enríquez, Wilfredo Lam and Víctor Manuel would continue this task.

The representations of black people in La Nova Catalunya evolved closely together with the processes of cultural mutation within both Cuban society and the Catalan intellectual community. The Catalan-Cuban intellectual community, in the figure of intellectuals like Jaume Valls and Fernando Ortiz, took part in Afrocubanismo as part of their own process of transculturation and also as part of both, the discursive readjustment and the wider restless process of cultural transfiguration within Cuban society that conducted to the reformulation of Cuban nationalism by the 1920s. Their intellectual journey includes the (dis)continuity and the contradictions addressed by Gilroy in his description of the richness of the processes of cultural mutation and exemplifies the phenomenon of becoming someone new in the transcultural realities of the Black Atlantic. Accordingly, the rise of Afrocubanismo and the reshaping of Cuban nationalism reached the pages of the journal of the Centre Català of Havana.

Without transcending an externalist and uncompromised point of view, Jaume Valls's sketching of black people, exemplifies the processes of reformulation of identities within artistic and political discourses about nation taking place in Cuba during the first half of the twentieth century. His work illustrates the assimilation of the claims of Afro-descendants and the incorporation of elements of the black cultures of Cuba to national discourse through Afrocubanismo by middle-class white intellectuals. The analysis of forms of stereotyping of black people by white middle-class intellectuals in this article shows the importance of bearing in mind the unequal disposition of power within different societies and communities while looking at stereotypes and their construction.

\section{Competing Interests}

The author has no competing interests to declare.

\section{References}

Augé, Marc. The War of Dreams: Studies in Ethno Fiction. Pluto Press, 1999.

Bagaria, Lluís. "Áuca cierta y verdadera d'en Joan Valldepera." La Nova Catalunya, 11, 10-11, 1908.

Bhabha, Homi. "The other question: the stereotype and colonial discourse." Visual Culture: a Reader, J. Evans and S. Hall (eds.), 370-78. Sage, 1983/1999.

Bojórquez, Juan de Dios. "Los minoristas de Cuba." Social, 12(6), 35, June 1927.

Cairo, Ana. El Grupo Minorista y su tiempo. La Habana, Editorial de Ciencias Sociales, 1978.

Conangla i Fontanilles, Josep. Elegia de La Guerra: Poesias: Impresions de La Guerra de Cuba. Tipografia Catalana, 1904.

---. El meu pare que al cel sia. Imprenta Monmany, 1920.

--. Eternal: Poesia i Prosa. A. Artís, 1921.

---. La ciudadania adoptiva. (Límite prudencial y legal de sus derechos y deberes) Contribución al estudio de una rama del derecho internacional privado. Imprenta moderna, 1916.

---. La Constitució Catalana de l'Havana i altres escrits. Edicions de la Magrana, 1986.

---. Martí y Cataluña: examen retrospectivo de unos conceptos inverisímiles, atribuidos al gran apóstol cubano. Comisión Nacional Organizadora de los Actos y Ediciones del Centenario y del Monumento a Martí, 1954.

---. Memoir of My Youth in Cuba: A Soldier in the Spanish Army During the Separatist War, 1895-1898. University of Alabama Press, 2017.

\footnotetext{
${ }^{18}$ Jaume Valls is the first of our artists resolved to devote himself to make Cuban art with Afrocuban types and traditions as its main motifs and themes.
} 
--.. "Paladines catalanes en defensa de los derechos y de la libertad de Cuba." La Nova Catalunya, 287, 16-27, May 1925.

Coronil, Fernando. "Introduction to the Duke University Press Edition. Transculturation and the Politics of Theory: Countering the Centre, Cuban Counterpoint." Cuban Counterpoint, F. Ortiz, ix-lvi. Duke University Press, 1995.

Costa, Lluís. La Llumanera de Nova York (1874-1881): la veu d'una burgesia catalana a favor d'una Cuba espanyola. Treballs de Comunicació. Societat Catalana de Comunicació, 19, 55-65, 2005.

Cuba Constitución Política, 1940.

Fanon, Franz. "The fact of blackness." Visual Culture: a Reader, J. Evans and S. Hall (eds.). 417-20. London: Sage, 1952/1999.

Ferran, Joan. La saga dels catalans a Cuba. Fundació Casa Amèrica Catalunya, 2009.

Foucault, Michel. "Preface." Anti-Oedipus. Capitalism and Schizophrenia, G. Deleuze and F. Guattari, xi-xxiv. The Athlone Press, 1985.

Gilroy, Paul. The Black Atlantic. Havard University Press, 1993.

Hall, Stuart. "Cultural identity and diaspora." Theorizing Diaspora: A Reader, J. E. Braziel and A. Mannur (eds.), 233-46. Blackwell Publishing, 2003.

--.. "The spectacle of the 'Other'." Representation: Cultural Representations and Signifying Practices, S. Hall (ed.), 223-90. Sage Publications, 1997.

Helg, Aline. "Fernando Ortiz ou la pseudo-science contre la socellerie Africaine á Cuba." La pensée métisse. Croyances africaines et rationalité occidentale en questions, R. Horton et al. (eds.). Presses Universitaires de France, 1990. DOI: https://doi.org/10.4000/books.iheid.3230

Helg, Aline. Our Rightful Share: The Afro-Cuban Struggle for Equality, 1886-1912. UNC Press Books, 2018.

Jerez Columbié, Yairen. Els Intelllectuals de "La Nova Catalunya" de L'Havana. Sept. 2014. Master thesis. Universitat de Girona. https://dugi-doc.udg.edu/handle/10256/10056.

---. Reimagining Catalonia from Havana: Transcultural Identities and Narratives of Nationalism in the Literature of the Catalanists of Cuba (1908-1959). 2018. PhD thesis. University College Cork. https://cora.ucc.ie/ handle/10468/7454.

La Nova Catalunya. "Cubans illustres, amics de Catalunya: El Dr. Ferran Ortiz." La Nova Catalunya, 332, 13-15, February 1929.

---. "Dr. Ferran Ortiz, soci meritíssim del Centre Català, advocat prestigiós i Representant a la Càmara Legislativa de Cuba qui donà el dia 11 de Setembre notable conferència al Centre Català." La Nova Catalunya, 209, 7, October 1918.

Moore, Robin D. Nationalizing Blackness: Afrocubanismo and the Artistic Revolution in Havana, 1920-1940. University of Pittsburgh Press, 1997. DOI: https://doi.org/10.2307/j.ctt5vkh3b

Ortiz, Fernando. Contrapunteo cubano del tabaco y el azúcar. Biblioteca Ayacucho, 1940/1977.

---. Cuban Counterpoint. Alfred A. Knopff, 1947.

---. "Discurs pronunciat l'onze de setembre al Centre Català." La Nova Catalunya, 208, 21-27, September 1918.

---. "El Dr. Mimó, 'Amigo del País'." La Nova Catalunya, 839, 8, September 1929.

---. Hampa afro-cubana: Los negros brujos (apuntes para un estudio de etnología criminal). Librería de F. Fé, 1906.

---. "Los factores humanos de la cubanidad." Perfiles de la Cultura Cubana, 1-15, May-December 2002/1949.

Poumier, Maria. “Fernando Ortiz (1881-1969), troisième découvreur de Cuba." Espace Caraïbe, 1, 81-93,1993.

Roig de Leuchsenring, Emilio. El grupo minorista de intelectuales y artistas habaneros. Oficina del Historiador de la Ciudad, 1961.

Roig de Leuchsenring, Emilio. "Un animador de tipos afrocubanos." Revista Social, 12, 18-19, 68, 94, December 1927.

Rojas, Rafael. Essays in Cuban Intellectual History. Springer, 2008. DOI: https://doi.org/10.1057/9780 230611078

Roy, Joaquín. "Poesía y Memorias de Josep Conangla i Fontanilles Sobre La Guerra de Cuba." Revista Iberoamericana, vol. 55, no. 146, June 1989, pp. 129-59. revista-iberoamericana.pitt.edu. DOI: https:// doi.org/10.5195/REVIBEROAMER.1989.4550

Torres Cuevas, E. "La sociedad esclavista y sus contradicciones." La colonia, evolución socioeconómica y formación nacional de los orígenes hasta 1867, Instituto de Historia de Cuba (ed.), 276-81. Editora Política, 1994.

Valls, Jaume. "El músic de les maraques" (drawing). La Nova Catalunya, cover page, June 1927.

--.. "El músic del bongo" (drawing). La Nova Catalunya, cover page, August 1927. 
How to cite this article: Jerez Columbie, Y 2020 Sketches of Black People by White Catalan-Cuban Intellectuals: Transculturation in Fernando Ortiz's and Jaume Valls's Afrocubanismo in 1920s Havana. Anthurium, 16(2): 5, 1-11. DOI: https://doi.org/10.33596/anth.362

Published: 21 December 2020

Copyright: $\odot 2020$ The Author(s). This is an open-access article distributed under the terms of the Creative Commons Attribution 4.0 International License (CC-BY 4.0), which permits unrestricted use, distribution, and reproduction in any medium, provided the original author and source are credited. See http://creativecommons.org/licenses/by/4.0/. 